\title{
Impact of psychological capital on employee engagement, job satisfaction and employee performance in the manufacturing sector in Zimbabwe
}

\begin{tabular}{|c|c|}
\hline \multicolumn{2}{|c|}{$\begin{array}{l}\text { Authors: } \\
\text { Bongani Ngwenya }{ }^{1} \\
\text { Theuns Pelser }{ }^{1}\end{array}$} \\
\hline \multicolumn{2}{|c|}{$\begin{array}{l}\text { Affiliations: } \\
{ }^{1} \text { Graduate School of Business } \\
\text { and Leadership, College of } \\
\text { Law and Management } \\
\text { Studies, University of } \\
\text { KwaZulu-Natal, Durban, } \\
\text { South Africa }\end{array}$} \\
\hline \multicolumn{2}{|c|}{$\begin{array}{l}\text { Corresponding author: } \\
\text { Bongani Ngwenya, } \\
\text { drbonganingwenya } \\
\text { @gmail.com }\end{array}$} \\
\hline \multicolumn{2}{|c|}{$\begin{array}{l}\text { Dates: } \\
\text { Received: } 27 \text { Jan. } 2020 \\
\text { Accepted: } 27 \text { May } 2020 \\
\text { Published: } 03 \text { Aug. } 2020\end{array}$} \\
\hline \multicolumn{2}{|c|}{$\begin{array}{l}\text { How to cite this article: } \\
\text { Ngwenya, B., \& Pelser, T. } \\
\text { (2020). Impact of } \\
\text { psychological capital on } \\
\text { employee engagement, } \\
\text { job satisfaction and } \\
\text { employee performance in } \\
\text { the manufacturing sector in } \\
\text { Zimbabwe. SA Journal of } \\
\text { Industrial Psychology/SA } \\
\text { Tydskrif vir Bedryfsielkunde } \\
\text { 46(0), a1781. https://doi. } \\
\text { org/10.4102/sajip.v46i0.1781 }\end{array}$} \\
\hline \multicolumn{2}{|c|}{$\begin{array}{l}\text { Copyright: } \\
\text { (c) 2020. The Authors. } \\
\text { Licensee: AOSIS. This wo } \\
\text { is licensed under the } \\
\text { Creative Commons } \\
\text { Attribution License. }\end{array}$} \\
\hline \multicolumn{2}{|l|}{ Read online: } \\
\hline 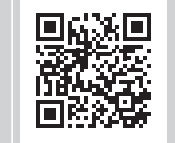 & $\begin{array}{l}\text { Scan this QR } \\
\text { code with your } \\
\text { smart phone or } \\
\text { mobile device } \\
\text { to read online. }\end{array}$ \\
\hline
\end{tabular}

Orientation: Human capital lies at the heart and centre of any organisation's success. It is for this reason that entrepreneurial envisioned corporations embrace the role of psychological capital in order to optimise their employees' competences and potential.

Research purpose: The study underscores the role that psychological capital plays on employee engagement, job satisfaction and employees' performance in the manufacturing sector of a developing country context.

Motivation for the study: The study was motivated by the need to assess the impact of psychological capital on employee engagement, job satisfaction and employee performance in the manufacturing sector organisations.

Research approach/design and method: Quantitative approach and design was used in this study, with 257 respondents selected from 15 manufacturing firms based in Bulawayo, Zimbabwe. Collected data were analysed using structural equation modelling (SEM) technique.

Main findings: The results showed that psychological capital significantly positively influence employee engagement, job satisfaction and employee performance. Employee engagement significantly positively influences employee performance and mediate the influence of psychological capital on employee performance. Whilst job satisfaction positively influences employee performance and employee engagement, respectively, it mediates the influence of psychological capital on employee performance.

Practical/managerial implications: Human capital drives organisational success. The manufacturing companies' management need to maximise their human capital core-competence by strategically embracing psychological capital to optimise employees' performance.

Contribution/value-added: This study extends the theoretical academic debate on psychological capital, its effects on employee engagement, job satisfaction and employee performance beyond the current and existing discoveries.

Keywords: psychological capital; employee engagement; job satisfaction; employee performance; manufacturing sector.

\section{Introduction}

The Confederation of Zimbabwe Industries' (CZI, 2018) manufacturing survey released in 2018 revealed that the resuscitation of manufacturing sector has become a big challenge and will preoccupy the Zimbabwean government into the near future. The growth of manufacturing output, which had reflected an upswing in 2017 as compared to 2016, appeared to trend downwards for most of the products, except for non-metallic mineral products. The year 2018 was generally characterised by declining growth rate of manufacturing sector. As indicated in the CZI report, only three subsectors (chemicals and petroleum products; drinks, tobacco and beverages; and non-metallic products) out of eight subsectors recorded higher growth rate in 2018 as compared to 2017. However, these three subsectors caused and leveraged the overall growth of manufacturing sector by about $12 \%$ in 2018. The investements made in 2018 caused the prevailing high growth rates in these three subsectors, that is foodstuffs, drinks, beverages and tobacco.

Since recovery from the hyperinflation of 2008, there has been a need to resuscitate the country's manufacturing sector in order to promote exports, as the country's manufacturing sector has found it hard to export because of general operating business environment. At the same time, the business environment has been fraught with declining job satisfaction, employee engagement and worker 
performance (Nguwi, 2014) The CZI survey report has indicated that domestic products are failing to compete in the global market because of unsustainable production costs and low production capacity. These challenges have forced most of the manufacturing firms to focus on producing products for domestic market only. There is a need for the manufacturing sector in Zimbabwe to focus on strategies to actively engage workers to improve worker performance in the sector and increase productivity beyond meeting domestic demand. The manufacturing sector needs to start exporting products in order to improve the inflow of foreign currency into economy (Ncube \& Jerie, 2012; Nguwi, 2014). High levels of employee engagement and job satisfaction are critical in achieving worker productivity and ultimately organisational performance. These dimensions in their mediating roles on how psychological capital could boost employee performance would be critical for manufacturing firms in Zimbabwe (Ncube \& Jerie, 2012).

This study proposes that at organisational level, the manufacturing sector in Zimbabwe must engage in psychological capital development, particularly sustained employee engagement. Ncube and Jerie (2012) in their research focusing on the hospitality industry in Zimbabwe concluded that employee engagement plays a critical role in the performance of employees and the overall competitiveness of companies. Whilst several studies have been conducted on the levels of employee engagement, the benefits of employee engagement on organisational performance in the Zimbabwean manufacturing sector have not been fully explored, and particularly the mediation role that employee engagement plays in explaining the influence of psychological capital on employee performance (Anderton \& Bevan, 2014; Ncube \& Jerie, 2012; Nguwi, 2014). Positive psychology could have significant influence on the required levels of psychological capital development, which would possibly influence the desired behaviour and attitudes of manufacturing firms' employees to commit to organisational reasons of existence and contribute towards the resuscitation of country's manufacturing sector's capacity (Anderton \& Bevan, 2014).

\section{Manufacturing capacity utilisation in Zimbabwe}

The sector's capacity utilisation reached its all-time low record of $10 \%$ in 2008; however, it gained significantly to $57 \%$ in 2011 owing to the adoption of multicurrency regime. Subsequently, capacity fluctuated, falling to $34.3 \%$ in 2015 , picking up again to $47.4 \%$ in 2016 before dropping marginally to $45.1 \%$ in 2017 . With an average increase of 3.1\% from September 2017 to August 2018, capacity utilisation increased from $45.1 \%$ recorded for 2017 to $48.2 \%$ in 2018. Figure 1 shows the capacity utilisation trend for the period 2011-2018.

According to the CZI's (2018) manufacturing sector survey, there is strong potential for the country to increase its manufacturing sector's capacity utilisation beyond $70 \%$ by 2023, provided the existing structural and economic impediments negatively impacting the sector are addressed accordingly.

\section{Volume of manufacturing index}

The volume of manufacturing index (VMI), that is, measuring change in the volume of production of goods, has continued to decline since 2009, despite all the potential for growth that exists in the sector. Figure 2 shows the volume of the manufacturing index over the period 2009-2016.

Despite the noticeable stagnancy in the manufacturing sector as a whole, different subsectors have registered mixed results throughout. Noticeable for better performance is the non-metallic mineral products subsector. This subsector's performance has been rising consistently since 2009. As of 2015, the subsector's performance had improved by over $40 \%$ compared with its 2009 levels. Figure 3 shows this subsector's performance improvement.

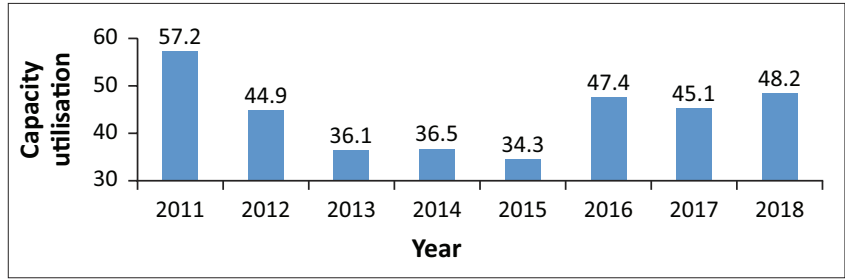

Source: Confederation of Zimbabwe Industries (CZI) (2018). Import substitution, value addition and export promotion, manufacturing sector survey. Harare: Confederation of Zimbabwe Industries.

FIGURE 1: Manufacturing sector's capacity utilisation.

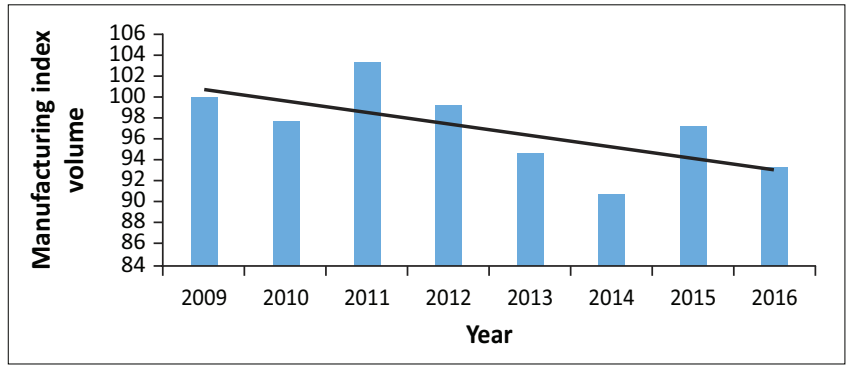

Source: Zimbabwe National Statistics Agency (ZimStats). (2017). Manufacturing Industry Suervey. Harare: Zimbabwe National Statistics Agency.

FIGURE 2: Volume of manufacturing index for the Zimbabwe manufacturing sector (2009-2016).

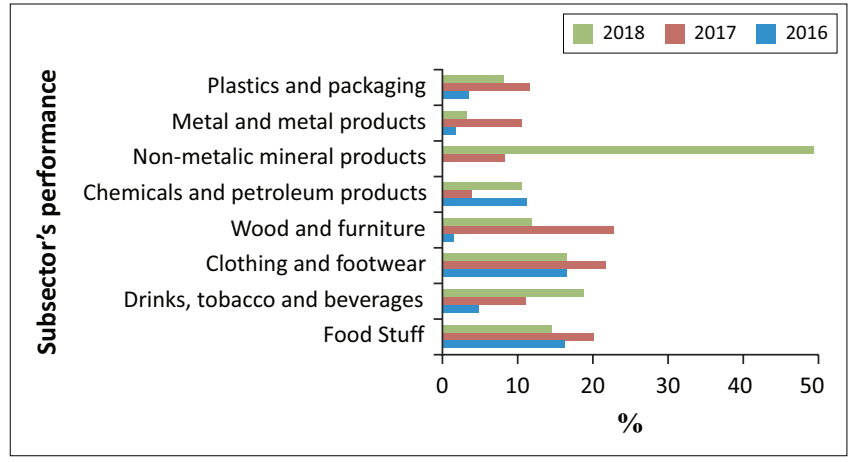

Source: Confederation of Zimbabwe Industries (CZI) (2018). Import substitution, value addition and export promotion, manufacturing sector survey. Harare: Confederation of Zimbabwe Industries.

FIGURE 3: The Zimbabwe manufacturing subsector output growth rate (percentage), 2016-2018. 
The subsectoral performance analysis conducted by VMI in the Zimbabwe National Industrial Policy (ZNIDP) is divided into two categories: the first category showing the subsectors that reported positive performance, and the second one showing the subsectors that reported negative performance during the period under examination. For example, the wood and furniture subsector registered increased performance close to $40 \%$, a significant increase in performance as of 2013 against the 2009 levels.

This momentum was sustained through 2015. On the other hand, until 2014, the foodstuffs subsector continued to be depressed in comparison to 2009, however rising steadily thereafter. The clothing, metals and metallic, and the textiles subsectors were the worst performers and on whole negatively affected the performance of the manufacturing sector in serious terms. However, the textiles subsector showed some degree of improvement in 2016.

\section{Manufacturing sector's contribution to gross domestic product}

According to Zimstat (2018), the manufacturing sector's contribution to the country's gross domestic product (GDP) plummeted during the period 2000-2009. This period is inclusive of the hyperinflation era. The post-multi-currency period saw the sector contributing to the GDP its highest output growth of US $\$ 1157$ million (m) to US $\$ 2004 \mathrm{~m}$ between 2009 and 2010. It experienced an increase of $13.8 \%$ to US $\$ 2282 \mathrm{~m}$ in 2011 and an increase of 5.3\% in 2012. Thereafter, the sector's contribution grew at an average of $1.3 \%$ through 2017. To date, the contribution of the manufacturing sector to the country's GDP has fallen from about $25 \%$ in the 1990 s to about $12 \%$, largely because of a coterie of impediments such as foreign exchange shortage, liquidity crunch and the general adverse economic environment. Figure 4 shows the manufacturing sector's contribution to the GDP of the country over the period 2009-2017.

Following challenges that the manufacturing sector in Zimbabwe has been experiencing, especially postdollarisation and its critical contribution to socio-economic

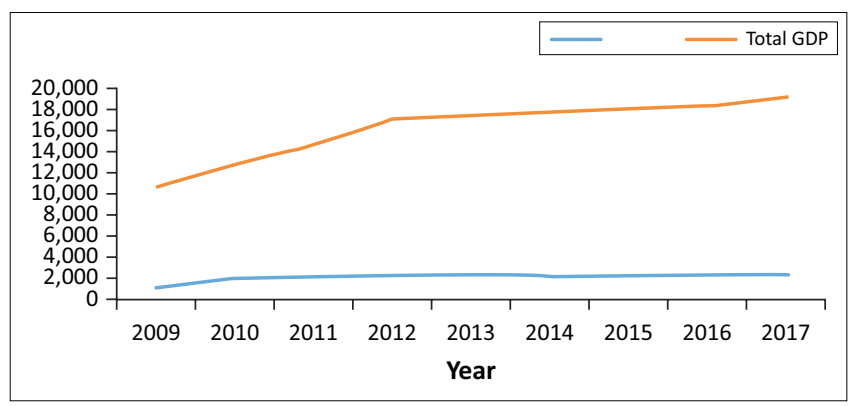

Source: Zimbabwe National Statistics Agency (ZimStats) (2017). Manufacturing industry survey. Harare: Zimbabwe National Statistics Agency.

GDP, gross domestic product.

FIGURE 4: Manufacturing sector's gross domestic product contribution at constant (2012) prices (in million US\$). development and the GDP of the country, this study posits a strategic consideration of employing psychological capital (Du Plessis \& Barkhuizen, 2012; Eustace \& Martins, 2014). It is critical to understand the value of having stability in the manufacturing sector in terms of employees' commitment to their organisations, especially in the context of erratic business environment prevailing in Zimbabwe. This study proposes that more is to be performed to enhance psychological capital in the country's manufacturing sector. Despite the potential of positive impact of the manufacturing sector on Zimbabwe's economy, there are some environmental factors that affect the stability of labour force posed by the ailing economy. These environmental factors include job insecurity and job loss, pessimistic future, hopelessness and growing unemployment in the Zimbabwean labour market in general (Du Plessis \& Barkhuizen, 2012; Eustace \& Martins, 2014).

\section{Theoretical foundation of the study}

\section{Employee performance}

Employee performance is the result of work carried out by employees in terms of both quality and quantity in relation to the responsibilities assigned by an organisation (Mangkunegara, 2015). Employee performance, according to Fahmi (2018), refers to the results obtained by organisations, regardless of these being profit or non-profit making organisations, during a given period. In other words, performance is what workers do in organisations. According to Mathis and Jackson (2006), the question is regarding the quality of work performed, that is, has the ideal work been performed in accordance with organisational demands? Nevertheless, Iktiagung and Pratiwi (2014) have a different view that psychological capital does not influence organisational employee performance.

In measuring organisational success, optimal organisational performance is the key. According to Nengah, Kertiriasih, Sujana and Suardika (2018), organisations view employee performance from the perspective of achieving targeted objectives and goals. Organisational employee performance is a measure of both quality and quantity results in the execution of tasks in accordance with the responsibilities assigned by the organisation (Pratama \& Aima, 2018). Njoroge and Kwasira (2015) suggest that most of the organisations fail to maximise the human resource management function because the performance of their workers does not measure up to their expectations and targets.

Pratama and Aima's (2018) study results indicate that what affects organisational employees' performance is their engagement in organisations. According to Anitha (2014), a strong and significant relationship does exist between organisational employee engagement and organisational employee performance. These views are in support of the results of the study conducted by Heriyati and Ramadhan (2012). Ncube and Jerie (2012), in their study conducted in the hospitality sector, have reiterated the need for corporations 
to leverage their employees' performance, especially during economic distress and resuscitation of country's economy.

\section{Psychological capital}

Psychological capital is an important phenomenon of the emerging concepts of positive psychology and positive organisational behaviour (POB). According to Luthans, Avolio, Avey, Norman and Norman (2007), positive psychology is an emerging science that focuses on the improvement of people's lives. Positive organisational behaviour should be measured and managed to enhance organisational employee performance (Aziz, 2016; Kementerian Perindustrian, 2019).

Literature proffers four capacities of psychological capital assets, namely self-efficacy, resilience, hope and optimism, as criteria to meet POB. These factors are indicators or measures of psychological capital of individuals (Luthans et al., 2007). Luthans, Avolio, Avey, Norman and Norman (2008) indicate that psychological capital, as an indicator of individual's positive psychological development, is portrayed by (1) individual having confidence (self-efficacy) in executing challenging tasks, followed by (2) individual exhibiting positive attribution (optimism) about being successful now and in the future.

This is followed by (3) the individual's persistence in the execution of organisational objectives and mapping the direction of achieving those objectives (expectations) successfully and (4) the individual's ability to forge ahead in the face of difficulties (resilience) towards overcoming the problems and achieving success (Rini, 2018; Yasmin, 2018). Luthans et al. (2007) suggest that psychological capital begins with the influence of psychology practitioners in organisations. With negative vibes and approaches stimulating employees to rather focus on realising their personal interests and needs, they are attracted to solving only short-term problems. Negative approaches manifest in employees' emotional conditions of burn out, conflicts, stress and disengagements (Luthans et al., 2008). If there is a lack of effectiveness of negative approaches, then positive approaches arise, according to the research conducted by Seligman (2011), that focus on the health of employees.

The study concluded that employees would become happy, more productive and unleash their full potential (Luthans et al., 2008). This results in positive psychology that stimulates $\mathrm{POB}$ at individual employee level and positive organisational scholarship (POS) at organisational level (Luthans et al., 2008).

Psychological capital, as a positive situational driver for selfdevelopment, self-efficacy, optimism, hopefulness and endurance stimulator, is viewed as a positive catalyst for optimal employee engagement, employee's job satisfaction and employee performance (Fedai \& Kapusuz, 2015). Psychological capital has positive impact in continuous competitiveness. Literature suggests that the positive impact of psychological capital is mainly the reduction of costs of negative organisational influence, as employees become more engaged, are satisfied with their jobs and hence performance is improved (Fedai \& Kapusuz, 2015).

Psychological capital as a positive state of personal development manifests itself in hope, optimism, self-efficacy and resilience - the primary dispositional predictor of employee engagement (Luthans et al., 2008). These positive motivational states lead to higher levels of employee engagement (Luthans et al., 2008). Thus, giving the rationale for the study, we hypothesise as follows:

$\mathbf{H}_{1}$ : There is a significant positive influence of psychological capital on employee engagement.

Some studies bring in the dimension of psychological capital and its effect on job satisfaction. Studies such as Zaman and Tjahjaningsih (2017) and Nafei (2015) have discovered that a positive significant relationship does exist between psychological capital and employee job satisfaction. These assertions derive the rationale for this study to hypothesise as follows:

$\mathbf{H}_{2}$ : There is a significant positive influence of psychological capital on job satisfaction.

Literature suggests that psychological capital also affects and influences employee performance (Nafei, 2015). Abbas, Raja, Darr and Bouckenooghe (2012) intimate that psychological capital affects organisational employee performance directly, positively and significantly in measuring and prompting this study to hypothesise as follows:

$\mathbf{H}_{3}$ : There is a significant positive influence of psychological capital on employee performance.

\section{Employee engagement}

Employee engagement is an intellectual and emotional bond towards organisational commitment by employees and is exhibited in three distinct behaviours. The first distinct behaviour is talking positive about organisations to customers and stakeholders by their employees. The second behaviour is employees demonstrating high enthusiasm for becoming members of the organisation. The last distinct behaviour is when employees achieve bigger results and effort to contribute to organisational success (Lockwood, 2007).

According to Sihag and Sarikwal (2014) and Costantini, Paola, Ceschi and Sartori (2017), there is a positive relationship between psychological capital and organisational employee engagement. However, Kurniadewi (2016) explains that the relationship is not significant. In addition, as argued by Macey and Schneider (2015), employees who are engaged to demonstrate positive intentions to be bound with the organisation and their enthusiasm to work is high, they become attached to their jobs, tend to work an extra mile with undivided dedication to the job they are doing. They master the art of doing work through proactive thinking towards the achievement of organisational goals. 
Schaufeli, Salanova, Bakker and Alez-rom (2002) view employee engagement as a positive phenomenon that is full of purposeful meaning, motivation and vigour and vitality characterised by unquestionable dedication to the organisation. Employee engagement defines or measures emotional bonding, positively or negatively. It influences employees' attitudes towards their jobs, towards their friends and towards the organisation at large.

Several authors define employee engagement as a voluntary inner drive that results in higher performance.

Ultimately, employee engagement affects employees' intentions to study and improve their organisational performance. Harter, Schmidt and Hayes (2002) reiterate that employee engagement is critical for business success and overall performance of organisational employees. Ncube and Jerie (2012) have found that employee engagement has positively influenced employees' performance in the hospitality industry of Zimbabwe.

However, Chen (2019) suggests that employee engagement is more of a mediator variable, that is, it mediates the positive influence of psychological capital on employee performance. Employee engagement is important for organisations to achieve higher levels of productivity and performance. In this modern competitive business world, employee engagement could be achieved optimistically in a psychological capitalconducive environment to enhance higher levels of employee performance. Hence, based on the above rationale, the following hypothesis is proposed:

$\mathbf{H}_{4}$ : Employee engagement mediates the influence of psychological capital on employee performance.

\section{Job satisfaction}

Job satisfaction affects and closely influences employee's organisational performance. The results of the study conducted by Heriyati and Ramadhan (2012) and Platis, Reklitis and Zimeras (2015) underscore that employee satisfaction positively influences employee performance in an organisation. However, in the studies performed by Amilin (2016) and Supiyanto (2015), the results are that job satisfaction does not significantly affect organisational employee performance. In another research conducted by Nengah et al. (2018), the results indicated that job satisfaction significantly and positively influences employee performance. Nevertheless, Kaplan and Mehmet (2013) have concluded that there is no significant link between self-efficacy and the expectations of psychological capital, which is a sub-dimension of job satisfaction.

Thus, the greater the employee's job satisfaction, the greater the levels of employee's engagement (Kaplan \& Mehmet, 2013).

Tepayakul and Rinthaisong (2018) suggest that there is a direct positive force between employee job satisfaction and organisational employee engagement. These authors' study was in support of the results of the study carried out by Deshwal (2015), which showed that there is indeed a positive relationship between employee job satisfaction and organisational employee engagement. This rationale prompted the researchers to propose the following hypothesis:

$\mathbf{H}_{5}$ : There is a significant positive influence of job satisfaction on employee engagement.

Job satisfaction, based on the views of Mangkunegara (2015), relates to feelings that push employees to relate to their jobs or conditions. Job satisfaction reflects employee performance in terms of their creativity, their tastes and their intentions they exhibit as individuals (Suparyadi, 2015). On the other hand, job satisfaction is considered to be a positive behaviour that reflects the results of evaluation of employee expectations and realities of their work in relation to their remuneration. Satisfaction is derived when employees' needs are met in relation to or comparison with other employees in similar organisations and industry, and when remuneration is commensurate with job demands (Robbins, 2006).

Several studies have dealt with the mediating effect of job satisfaction between several variables. In a study performed by Ibrahim and Boerhaneoddin (2010) on the relationships between worker performance, job satisfaction, psychological capital, organisational commitment and work burnout, the authors concluded that job satisfaction mediated the relationship between studied independent and dependent variables of psychological capital and employee performance. In consideration of these findings, this study hypothesised as follows:

$\mathbf{H}_{6}$ : Job satisfaction mediates the influence of psychological capital on employee performance.

\section{Research design Research approach}

Figures 5-7 depict the proposed conceptual frameworks for the study.

In Figure 5, the study first conceptualises that there is a positive significant relationship between psychological capital and employee engagement (Costantini et al., 2017; Herlina and Mujib, 2017; Jung, Kang, \& Busser, 2018; Kurniadewi, 2016; Sihag \& Sarikwal, 2014; Suharianto \& Effendy, 2015; Thompson, Lemmon, \& Walter, 2015). Secondly, psychological capital also directly influences and affects employee performance (Abbas et al., 2012; Luthans et al., 2008; Nafei, 2015; Zaman \& Tjahjaningsih, 2017). According to Nafei (2015), psychological capital positively affects employee performance while employee engagement mediates the relationship between the two factors. The dotted arrow in the

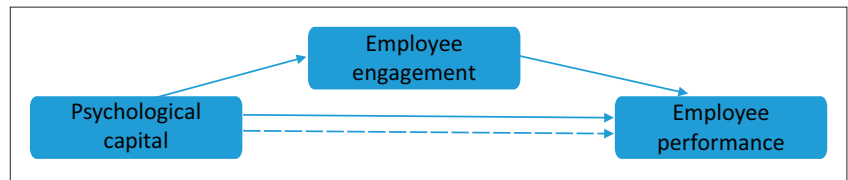

FIGURE 5: Conceptual and research framework 1. 


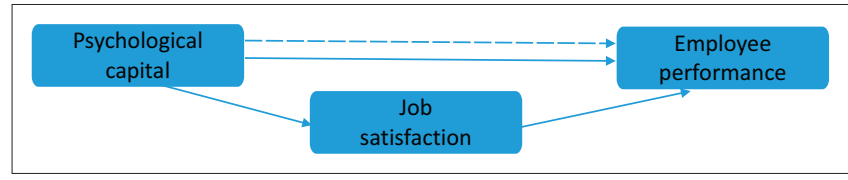

FIGURE 6: Conceptual and research framework 2.

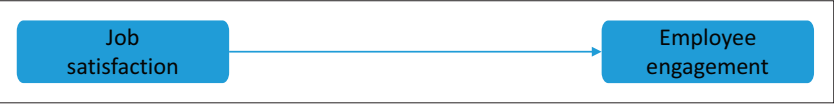

FIGURE 7: Conceptual and research framework 3.

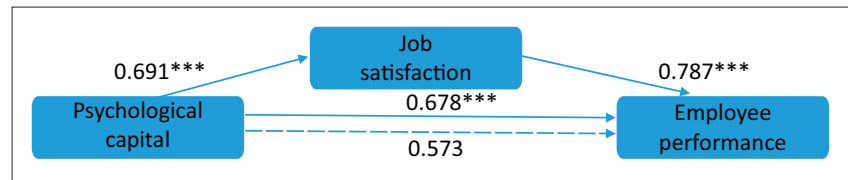

Note: The solid arrows between the variables denote direct paths, whilst the dotted arrow denotes the beta coefficient of equation, including both psychological capital and employee engagement as predictors of employee performance. The values denote standard beta weights ( $\beta$ )

FIGURE 8: Employee engagement mediation analysis results.

conceptual framework in Figure 5 denotes this relationship. The study also conceptualises that employee engagement positively and significantly influences employee performance (Agung, Prabasari, Kadek, Martini, \& Suardika 2018; Anitha, 2014; Heriyati \& Ramadhan, 2012; Mariska, 2018; Nengah et al., 2018; Pratama \& Aima, 2018).

As depicted in Figure 6, the study proposes that psychological capital positively and significantly influences and affects job satisfaction (Bergheim, Birkeland, Mearns, \& Eid, 2015; Luthans et al., 2007; Mello \& Hartford, 1962; Nafei, 2015; Parthi \& Gupta, 2016; Salam, 2017; Zaman \& Tjahjaningsih, 2017). Nevertheless, results of the studies performed by Abbas et al. (2012) and Kaplan and Mehmet (2013) were in contrast, and instead suggest that job satisfaction mediates the influence of psychological capital on employee performance. The dotted arrow in Figure 7 denotes this relationship. It is also conceptualised that job satisfaction positively and significantly influences employee performance (Amilin, 2016; Gu \& Siu, 2009; Heriyati \& Ramadhan, 2012; Mariska, 2018; Nengah et al., 2018; Platis et al., 2015)

Lastly, the study proposes that there is positive and significant influence of job satisfaction on employee engagement as shown in Figure 8 (Deshwal, 2015; Kaplan \& Mehmet, 2013 Mariska, 2018; Nengah et al., 2018; Tepayakul \& Rinthaisong, 2018).

\section{Research methodology Respondents}

The population of the study consisted of eight manufacturing firms in Bulawayo with a total employee complement of 759.

From this population, 257 respondents were randomly selected using the Krejcie and Morgan's formula. The distribution of the sample was carried out according to the manufacturing sector companies as depicted in Table 1. The drinks, tobacco
TABLE 1: Demographic characteristics of respondents.

\begin{tabular}{llcc}
\hline Items & Category & Frequency & $\%$ \\
\hline Manufacturing & Plastic and packaging & 11 & 4.3 \\
sector & Metal products & 13 & 5.1 \\
& Non-metallic products & 15 & 5.8 \\
& Chemical and petroleum & 36 & 14.0 \\
& Wood and furniture & 21 & 8.2 \\
& Clothing and footwear & 42 & 16.3 \\
& Drinks, tobacco and beverages & 67 & 26.0 \\
\multirow{5}{*}{ Gender } & Foodstuff & 52 & 20.0 \\
& Male & 151 & 59 \\
Age & Female & 106 & 41 \\
& Under 30 years & 68 & 26 \\
& 31-40 years & 117 & 46 \\
\multirow{5}{*}{ Education level } & 47 & 18 \\
& Above 50 years & 25 & 10 \\
& High school certificate & 63 & 25 \\
& Diploma certificate & 71 & 28 \\
Years of & Degree certificate & 75 & 29 \\
experience & Postgraduate certificate & 48 & 19 \\
& Less than 5 years & 34 & 13 \\
\hline & 6-10 years & 145 & 56 \\
& Above 10 years & 78 & 30 \\
\hline
\end{tabular}

and beverages sub-manufacturing sector contributed the majority of the respondents, that is, $26 \%$ of the total respondents, followed by the foodstuffs sub-manufacturing sector with $20 \%$ of the total respondents, whilst plastic and packaging contributed the least at $4.3 \%$. Gender was skewed towards male respondents with $59 \%$ and females at $41 \%$, and $46 \%$ of the respondents were aged between 31 and 40 years.

In all, 26\% were aged less than 30 years and $10 \%$ were above 50 years. The majority of respondents $(29 \%)$ possessed at least a degree certificate qualification, followed by $28 \%$ with a diploma. More than half of the respondents (56\%) had between 6 and 10 years of work experience, whilst 30\% had more than 10 years' experience. A mere 13\% had less than 5 years of work experience.

\section{Research instrument}

The questionnaire was compiled using Qualtrics, an online survey-generating tool, which guarantees anonymity and confidentiality. The influence of psychological capital on employee engagement, job satisfaction and employee performance was measured on a five-point Likert scale. The following four indicators were adopted for psychological capital from Luthans et al. (2007): selfefficacy, optimism, hope and resiliency. These psychological subscales or indictors revealed acceptable level of reliability with a Cronbach's alpha coefficient of 0.7541 . In line with the study conducted by Schaufeli et al. (2002), employee engagement was measured by the following three subscales: dedication, vigour and absorption. Their level of reliability was acceptable with a Cronbach's alpha coefficient of 0.7801 .

Job satisfaction was measured using five indicators adopted from Robbins (2006). The indicators are satisfaction with rewards, satisfaction with autonomous authority, satisfaction with immediate supervisors, satisfaction with relationships amongst colleagues and satisfaction with promotion opportunities. These subscales revealed a satisfactory level of reliability, that is, a Cronbach's alpha coefficient of 0.6971, however, slightly below 0.7 . 
Five indicators such as attendance of employees, working time, quantity of work, quality of work and cooperation measured employee's performance (Mathis \& Jackson, 2006). These revealed a Cronbach's alpha coefficient of 0.7721 , which was deemed to be an acceptable level of reliability.

\section{Research procedure}

The study was not a commissioned study and as a result, it did not require any institutional review board approval.

The process started with an email providing a short explanation of the research, an invitation to participants to take part in the research: a link to an online instrument was sent to selected respondents. The participants were instructed to click on the link, which allowed them access to the online-designed questionnaire. The questionnaire bore clear instructions on how to complete it. The researchers allowed the invitation or the access link to remain active for a 4-week timeframe for the respondents to complete the questionnaire before the link became invalid. After first 2 weeks, the researchers sent reminder emails to potential respondents. After next 14 days, the survey was closed and data were exported into an IBM SPSS software version 22 for analysis.

\section{Data analysis}

The analysis of the data collected was performed by using structural equation modelling (SEM) technique, particularly the partial least square (PLS) method. With the aid of analysis of moments structures (AMOS) in SPSS version 23, the model fit was determined for goodness of fit index (GFI), the comparative fit index (CFI) and the root-mean-standarderror of approximation (RMSEA). According to $\mathrm{Hu}$ and Bentler (1999), a model is deemed to be having good fit when its CFI and GFI are at least 0.9 and above, and the RMSEA lies between 0.05 and 0.08 .

\section{Ethical statement}

This article followed all ethical standards for a research without direct contact with human or animal subjects.

\section{Results}

\section{Internal reliability, alpha coefficients, composite reliability and correlations}

Measurement model validation was conducted to satisfy the validity, reliability and unidimensionality requirements at the beginning of the analysis of the data collected.

In Table 2, psychological capital, employee engagement, job satisfaction and employee performance constructs have factor loading values $>0.7$, meaning that the indicators measuring these constructs satisfied convergent validity. The analysis also indicates that psychological capital construct, employee engagement construct, job satisfaction construct and employee performance construct have average (AVE) values $>0.5$, meaning that these variables satisfied convergent validity. The constructs also satisfied reliability when all of them depicted composite reliability values of $>0.7$.

As shown in Table 3, the minimum AVE root value is 0.831 and the maximum correlation value is 0.787 . This maximum correlation between employee performance and employee engagement lies in the quadrant below the minimum AVE root value, meaning that all correlations are less than the AVE root values. These test results reflect that each variable of the study satisfied discriminant validity.

As shown in Table 4, the squared multiple correlation $\left(\mathrm{R}^{2}\right)$ value (0.528) with respect to employee engagement implies that employee engagement variability in the manufacturing sector in Bulawayo is attributed to psychological capital and job satisfaction to the extent of $52.8 \%$. The remaining $47.2 \%$ extent of variability is attributed to factors outside the model.

The $R^{2}$ value $(0.245)$ with respect to job satisfaction means that job satisfaction variability in the manufacturing sector in Bulawayo is attributable to psychological capital to the extent of $24.5 \%$, and the remaining $75.5 \%$ is attributable to other factors outside the model.

TABLE 2: Items description, internal reliability, composite reliability and convergent validity.

\begin{tabular}{|c|c|c|c|c|c|}
\hline Variable & Indicator & Factor & AVE & $\begin{array}{c}\text { Cronbach's } \\
\text { alpha }\end{array}$ & $\begin{array}{l}\text { Composite } \\
\text { reliability }\end{array}$ \\
\hline \multirow{5}{*}{$\begin{array}{l}\text { Psychological } \\
\text { capital }\end{array}$} & - & - & 0.754 & 0.889 & 0.930 \\
\hline & X.1 & 0.883 & - & - & - \\
\hline & $X .2$ & 0.886 & - & - & - \\
\hline & $X .3$ & 0.795 & - & - & - \\
\hline & $X .4$ & 0.884 & - & - & - \\
\hline \multirow{6}{*}{$\begin{array}{l}\text { Employee } \\
\text { engagement }\end{array}$} & - & - & 0.780 & 0.877 & 0.920 \\
\hline & Y1.1 & 0.879 & - & - & - \\
\hline & Y1.2 & 0.869 & - & - & - \\
\hline & Y1.3 & 0.886 & - & - & - \\
\hline & Y2.1 & 0.838 & - & - & - \\
\hline & Y2.2 & 0.892 & - & - & - \\
\hline \multirow[t]{6}{*}{ Job satisfaction } & - & - & 0.697 & 0.835 & 0.928 \\
\hline & Y2.3 & 0.753 & - & - & - \\
\hline & Y2.4 & 0.843 & - & - & - \\
\hline & Y2.5 & 0.872 & - & - & - \\
\hline & Y3.1 & 0.854 & - & - & - \\
\hline & Y3.2 & 0.819 & - & - & - \\
\hline \multirow{4}{*}{$\begin{array}{l}\text { Employee } \\
\text { performance }\end{array}$} & - & - & 0.772 & 0.891 & 0.949 \\
\hline & Y3.3 & 0.923 & - & - & - \\
\hline & Y3.4 & 0.884 & - & - & - \\
\hline & Y3.5 & 0.897 & - & - & - \\
\hline
\end{tabular}

AVE, average.

TABLE 3: Discriminant validity index summary.

\begin{tabular}{lccccc}
\hline Construct & AVE & PC & EE & JS & EP \\
\hline Psychological capital & 0.861 & 1.000 & - & - & - \\
Employee engagement & 0.876 & $0.691 * * *$ & 1.000 & - & - \\
Job satisfaction & 0.831 & $0.495 * * *$ & $0.546 * * *$ & 1.000 & - \\
Employee performance & 0.872 & $0.678 * * *$ & $0.787 * * *$ & $0.684 * * *$ & 1.000 \\
\hline
\end{tabular}

Note: Diagonal items are average variance extracted; off diagonals are square of correlation. AVE, average; PC, psychological capital; EE, employee engagement; JS, job satisfaction; $E P$, employee performance.

$* * *, p<0.001$ 
With regard to employee performance, the $R^{2}$ value (0.726) suggests that employee performance variability in the manufacturing sector in Bulawayo is attributed to psychological capital, employee engagement and job satisfaction to the extent of $72.6 \%$ and the remaining $27.4 \%$ is attributable to other factors outside the model.

\section{Mediation analysis}

To test the mediation hypothesis, employee engagement mediates the influence of psychological capital on employee performance, and job satisfaction mediates the influence of psychological capital on employee performance, and for this, a linear bivariate four-step multiple regression was performed (Baron \& Kenny, 1986). Firstly, psychological capital must significantly correlate with employee performance. Secondly, psychological capital must significantly correlate with the mediators of employee engagement and job satisfaction. Thirdly, employee engagement and job satisfaction must significantly correlate with employee performance. Finally, psychological capital and the two mediators are regressed onto employee performance, and the mediation effect is satisfied when the results are insignificant correlations between psychological capital and employee performance than they were originally observed (Baron \& Kenny, 1986).

As established in Table 3, there is significant correlation between psychological capital, employee engagement and employee performance. These results supported the need for the regression of psychological capital and employee engagement onto employee performance. The results of regression analysis indicate a strong support for mediation hypothesis, meaning that employee engagement mediates the influence of psychological capital on employee performance, as the direct influence $(\beta=0.573, p=0.061)$ of psychological capital on employee performance was not significant as shown in Figure 9.

After establishing in Table 5 that there was significant correlation between psychological capital, job satisfaction and employee performance, regression of psychological capital and job satisfaction onto employee performance was performed. The results of regression analysis indicate a strong support for mediation hypothesis, meaning that job satisfaction mediates the influence of psychological capital on employee performance, as the direct influence $(\beta=0.472$, $p=0.056$ ) of psychological capital on employee performance was not significant as shown in Figure 10.

Figure 10 depicts the measurement model for psychological capital and its influence on employee engagement, job satisfaction and employee performance.

The measurement model depicted in Figure 10 is interpreted in conjunction with the path coefficient statistical results shown in Table 6.
The positive path coefficient (0.5631) measuring the psychological capital's influence on employee engagement, with a $t$-statistics $(8.2081)>1.96$ and a probability $(0.0000)<0.05$, means that psychological capital is significantly and positively influencing employee engagement in the manufacturing sector of Bulawayo. As a result, hypothesis $\mathrm{H}_{1}$ (there is a significant positive influence of psychological capital on employee engagement in the manufacturing sector of Bulawayo) is accepted.

The positive path coefficient (0.4931) measuring the psychological capital's influence on job satisfaction, with a $t$-statistics $(7.815)>1.96$ and a probability $(0.0000)<0.05$, means that psychological capital is significantly and positively influencing job satisfaction in the manufacturing sector of Bulawayo. These results support hypothesis $\mathrm{H}_{2}$ (there is a significant positive influence of psychological capital on job satisfaction in the manufacturing sector of Bulawayo), which is accepted.

The psychological capital's influence on employee performance has a positive path coefficient (0.1652) with a $t$-statistics value $(2.0931)>1.96$ and a probability $(0.0370)<0.05$, meaning that psychological capital has

TABLE 4: Squared multiple correlations $\left(R^{2}\right)$.

\begin{tabular}{lc}
\hline Variable & $R^{2}$ \\
\hline Psychological capital & - \\
Employee engagement & 0.528 \\
Job satisfaction & 0.245 \\
Employee performance & 0.726 \\
\hline
\end{tabular}

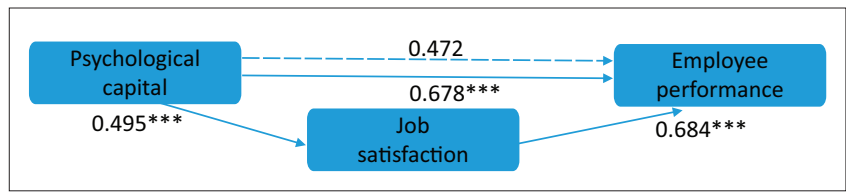

FIGURE 9: Job satisfaction mediation analysis results.

TABLE 5: Correlations of dependent and independent variables and mediators.

\begin{tabular}{llll}
\hline Dependent variable & $\begin{array}{l}\text { Independent } \\
\text { variable/mediator }\end{array}$ & $\boldsymbol{\beta}$ & Significance \\
\hline Employee engagement & Psychological capital & $0.691^{* * *}$ & 0.000 \\
Employee performance & Employee engagement & $0.787^{* * *}$ & 0.000 \\
Employee performance & Psychological capital & $0.678^{* * *}$ & 0.000 \\
& Employee engagement & 0.573 & 0.061 \\
Job satisfaction & Psychological capital & $0.495^{* * *}$ & 0.000 \\
Employee performance & Job satisfaction & $0.684^{* * *}$ & 0.000 \\
Employee performance & Psychological capital & $0.678^{* * *}$ & 0.000 \\
& Job satisfaction & 0.472 & 0.056 \\
\hline
\end{tabular}

$* * *, p<0.001$.

TABLE 6: Path coefficients.

\begin{tabular}{lllcccc}
\hline H & Variable & Connection & $\begin{array}{c}\text { Path } \\
\text { coefficients }\end{array}$ & t-statistics & $p$ & PS \\
\hline $\mathrm{H}_{1}$ & $\mathrm{PC} \mathrm{(X)}$ & $\rightarrow$ EE (Y1) & 0.5631 & 8.2081 & 0.0000 & Significant \\
$\mathrm{H}_{2}$ & $\mathrm{PC} \mathrm{(X)}$ & $\rightarrow$ JS (Y2) & 0.4931 & 7.8152 & 0.0000 & Significant \\
$\mathrm{H}_{3}$ & $\mathrm{PC} \mathrm{(X)}$ & $\rightarrow$ EP (Y3) & 0.1652 & 2.0931 & 0.0370 & Significant \\
$\mathrm{H}_{4}$ & $\mathrm{EE} \mathrm{(Y1)}$ & $\rightarrow \mathrm{EP}(\mathrm{Y} 3)$ & 0.4851 & 5.7303 & 0.0000 & Significant \\
$\mathrm{H}_{5}$ & JS (Y2) & $\rightarrow$ EP (Y3) & 0.3413 & 5.4432 & 0,0000 & Significant \\
$\mathrm{H}_{6}$ & JS (Y2) & $\rightarrow$ EE (Y1) & 0.2581 & 3.2999 & 0.0010 & Significant \\
\hline
\end{tabular}

$\mathrm{PC}$, psychological capital; $\mathrm{EE}$, employee engagement; JS, job satisfaction; EP, employee performance, $\mathrm{H}$, hypothesis; $\mathrm{PS}$, probability significance. 


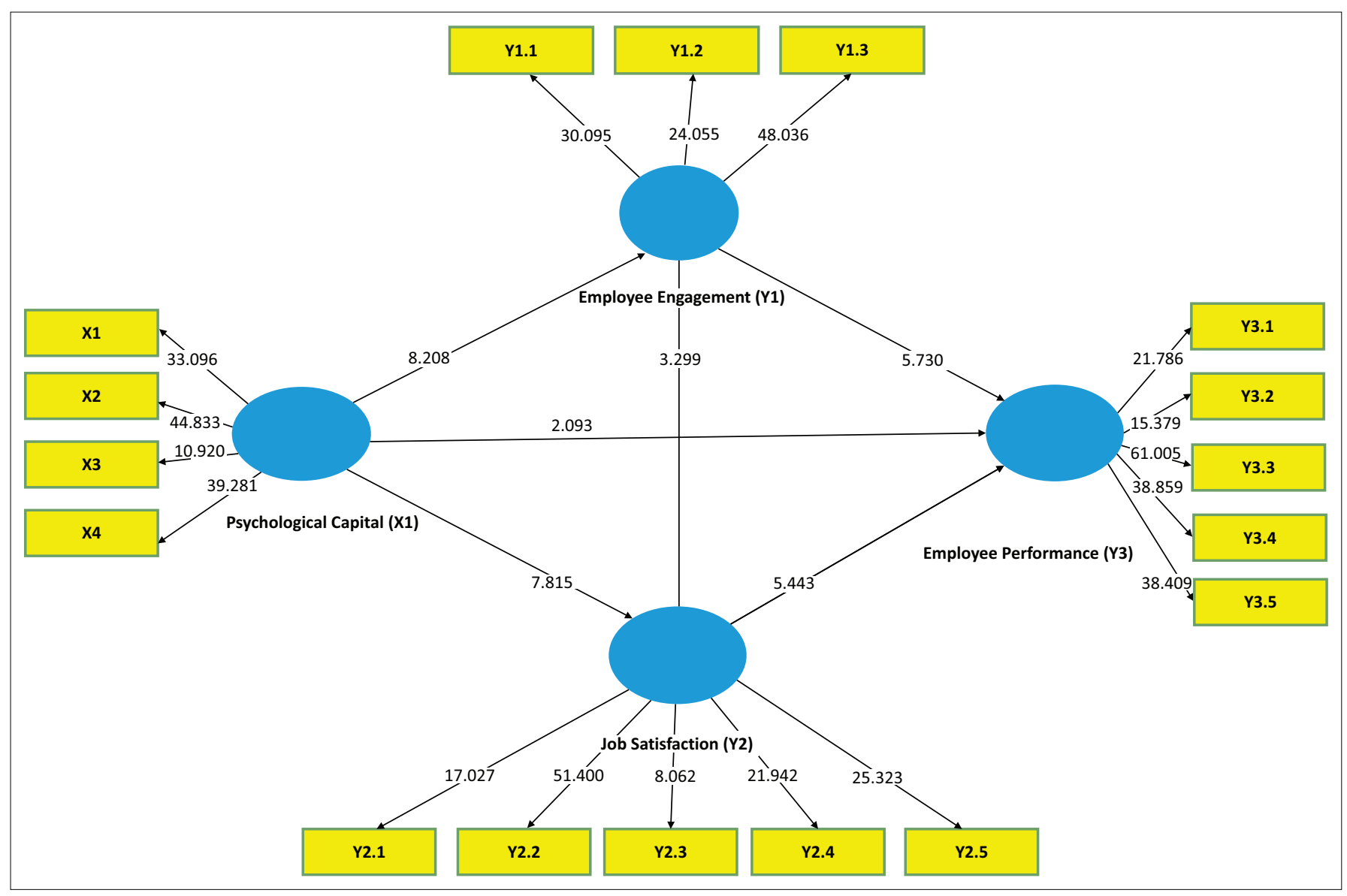

FIGURE 10: Measurement model.

a significant positive influence on employee performance in the manufacturing sector of Bulawayo. As a result hypothesis $\mathrm{H}_{3}$ (there is a significant positive influence of psychological capital on employee performance in the manufacturing sector of Bulawayo) is accepted.

The positive path coefficient (0.4851) measuring the influence of employee engagement on employee performance has a $t$-statistics $(5.7303)>1.96$ and a probability $(0.0000)<0.05$. These results indicate that employee engagement significantly and positively influences employee performance in the manufacturing sector of Bulawayo. Hypothesis $\mathrm{H}_{4}$ (there is a significant positive influence of employee engagement on employee performance in the manufacturing sector of Bulawayo) is accepted based on these results.

The positive path coefficient (0.3413) measuring the job satisfaction's influence on employee performance, with a $t$-statistics $(5.4432)>1.96$ and a probability $(0.0000)<0.05$, means that job satisfaction is significantly and positively influencing employee performance in the manufacturing sector of Bulawayo. As a result hypothesis $\mathrm{H}_{5}$ (there is a significant positive influence of job satisfaction on employee performance in the manufacturing sector of Bulawayo) is accepted.

Job satisfaction's influence on employee engagement has a positive path coefficient $(0.2581)$ with a $t$-statistics value $(3.2999)>1.96$ and a probability $(0.0010)<0.05$. The implication of the statistics is that job satisfaction significantly and positively influences employee engagement. These results support hypothesis $\mathrm{H}_{6}$ (there is a significant positive influence of job satisfaction on employee engagement in the manufacturing sector of Bulawayo), which is accepted.

\section{Discussion}

Managing human capital is critical for economies going through a recovering state such as Zimbabwe's economy.

Zimbabwe's economy is struggling to recover from the hyper-inflation era, particularly its manufacturing sector is battling low capacity utilisation. Literature suggests that human capital management plays an important role in enabling companies to regain their productive capacities. Strong human capital is a strategic core-competence that successful firms accumulate over time and manage to build their sustainable competitive advantage (Heriyati \& Ramadhan, 2012; Ibrahim \& Boerhaneoddin, 2010; Mariska, 2018; Nengah et al., 2018). Firms leverage their employees' performance in building their capacity utilisation and competitive advantage by employing as human capital management strategy, psychological capital management to optimise the performance of their workers.

Organisations that employ psychological capital management tend to experience high levels of employee engagement, job 
satisfaction and employee performance (Luthans et al., 2008; Nafei, 2015; Zaman \& Tjahjaningsih, 2017). Their employees excel in their work tasks.

Pursuant to the need to respond to a dynamic business environment, opportunities are presented for Zimbabwean organisations to explore means of enhancing productivity, especially in the manufacturing sector, means for competitiveness and sustainability of the sector on a global scale. In order to achieve global competitiveness, the manufacturing firms need to implement work environment intervention strategies to improve the psychological capital climate. It is envisaged that positive psychology could have significant influence on the required levels of psychological capital development, which would possibly influence the desired behaviour and attitudes of manufacturing firms' employees to commit to organisational reasons for existence and contribution towards the resuscitation of Zimbabwe's manufacturing sector's capacity utilisation.

\section{Theoretical implications}

Some theoretical implications could be derived from the results of this study. Firstly, the study revealed that psychological capital strongly and positively influences worker performance. Psychological capital drives the needed levels of employee engagement in organisations. Secondly, psychological capital props up job satisfaction. Employment of psychological capital has a potential to significantly increase the job satisfaction levels of employees in organisations even at times of economic distress.

Thirdly, the results revealed that employee engagement mediates the positive influence of psychological capital on employee performance. In other words, employee engagement buttresses psychological capital, as the two industrial psychology factors of human capital development positively and significantly influence employees' performance in organisations.

Fourthly, psychological capital's influence on employee performance is also mediated by job satisfaction. The more are the workers satisfied with their jobs, the higher is their performance. The results also revealed that job satisfaction influences employee engagement. In other words, as employees attain work satisfaction, the more they would like to be engaged in their work activities that enhance their performance.

\section{Managerial implications}

This study offers some key practical implications to human resource practitioners and the management of manufacturing firms in Bulawayo. From the results of the study, it is easy to understand the functions of psychological capital, employee engagement and job satisfaction in enhancing performance of employees in the manufacturing firms of Bulawayo. A prognosis that when employees are more engaged and satisfied with their jobs, higher are the chances that their performance growth is achieved. As a result, the manufacturing firms in Bulawayo should contemplate on ways to keep their workers engaged actively, and the human resource professionals and management should design strategies to keep the employees' job satisfaction levels high. Bearing in mind that the performance levels of workers depend on how engaged and how much satisfied employees with their jobs, it is paramount that the management of manufacturing firms invest in programmes of employee engagement and job satisfaction.

\section{Limitations and recommendations}

Every research is inherently limited. Although this study has set hypotheses considering the influence of psychological capital on employee performance, employee engagement, job satisfaction and the related sub-hypotheses, the first limitation is the restricted phenomenon context of the sample. The sample used in this study could possibly limit the generalisability of results of the study compared with that of studies conducted with samples of a wider scope and diversified characteristics. Therefore, the study recommends that the future research based on this study's model investigates samples with wider scope and more diverse characteristics in order to increase the generalisability of results. Secondly, the methodology employed in this study relied on cross-functional research, and as a result, the casualty between variables was not exploited comprehensively. Particularly the mediation effects of employee engagement and job satisfaction on the influence of psychological capital on employee performance were not explored rigorously. As a result, the authors recommend that the future longitudinal studies be conducted on the same topic to examine how changes in the engagement levels of employees and in job satisfaction levels in the long run affect the psychological capital influence on employee performance. Lastly, in general, there was a common method bias that existed because the study used a questionnaire for data collection. Qualitative data collection instruments such as interviews could have tapped into greater inner personal and silent opinions and perceptions of the participants.

\section{Conclusion}

This study has found that the more is the psychological capital engaged and employed, the more is the increase in employee engagement, as psychological capital positively and significantly influences employee engagement.

Boosting employee levels of job satisfaction improves organisational productivity in the economy, as psychological capital positively and significantly influences employee performance. The more and deeper are the employees engaged, the more is the increase in their performance levels. The higher levels of job satisfaction amongst employees in organisations are bound to increase employee performance significantly. The more are the employees satisfied with their jobs, the more are they willing to be engaged for the 
betterment of the organisations operating in a distressed economy.

\section{Acknowledgements Competing interests}

The authors declare that they have no financial or personal relationships that may have inappropriately influenced them in writing this article.

\section{Authors' contributions}

All authors contributed equally to this work.

\section{Funding information}

This research received no specific grant from any funding agency in the public, commercial or not-for-profit sectors.

\section{Data availability statement}

Data sharing is not applicable to this article as no new data were created or analysed in this study.

\section{Disclaimer}

The views and opinions expressed in this article are those of the authors and do not necessarily reflect the official policy or position of any affiliated agency of the authors.

\section{References}

Abbas, M., Raja, U., Darr, W.A., \& Bouckenooghe, D. (2012). Combined effects of perceived politics and psychological capital on job satisfaction, turnover
intentions, and performance. International Journal of Psychological, 40(7), 1-34. intentions, and performance. International Journ
https://doi.org/10.1177/0149206312455243

Agung, I.G., Prabasari, M., Kadek, L., Martini, B., \& Suardika, N. (2018). The effect of communication and employee engagement on organizational citizenship
behavior and employee performance in employees PT. PLN (Persero) distribution behavior and employee performance in employees PT. PLN (Persero) distribution of Bali. International Journal of Contemporary Research

Amilin, A. (2016). Measuring the correlation of job satisfaction with accountants' performance: The role of Islamic work ethics as a moderator. European Research Studies, XIX(4), 217-232. https://doi.org/10.1177/1046496406287311

Anderton, E., \& Bevan, S. (2014). Constrained work? Job enrichment and employee engagement in low wage, low skill jobs. Lancaster University: Bailrigg.

Anitha, J. (2014). Determinants of employee engagement and their impact on employee performance. International Journal of Productivity and Performance Management, 63(3), 308-323. https://doi.org/10.1108/IJPPM-01-2013-0008

Aziz, A. (2016). Titik nadir industri keramik. Retrieved from https://tirto.id/titik-nadir industri-keramik-bKTu.

Baron, R.M., \& Kenny, D.A. (1986). The moderator mediator variable distinction in social psychological research: Conceptual, strategic and statistical considerations. Journal of Personality and Social Psychology, 51(6), 1173-1182. https://doi.org/ 10.1037/0022-3514.51.6.1173

Bergheim, K., Birkeland, M., Mearns, K., \& Eid, J. (2015). The relationship between psychological capital, job satisfaction, and safety perceptions in the maritim industry. Safety Science, 74, 27-36. https://doi.org/10.1016/j.ssci.2014.11.024

Chen, C. (2019). Does work engagement mediate the influence of job resourcefulness on job crafting? An examination of frontline hotel employees. Internationa Journal of Contemporary Hospitality Management, 31(4), 1684-1701. https://doi. org/10.1108/IJCHM-05-2018-0365

Costantini, A., De Paola, F., Ceschi, A., \& Sartori, R. (2017). Work engagement and psychological capital in the Italian public administration: A new resource-based intervention programme. SA Journal of Industrial Psychology, 43(a1413), 0-11. https://doi.org/10.4102/sajip.v43i0.1413

Confederation of Zimbabwe Industries (CZI) (2018). Import substitution, value addition and export promotion, manufacturing sector survey. Harare: Confederation of Zimbabwe Industries.

Deshwal, S. (2015). A study of job satisfaction in relation to employee engagement. International Journal of Applied Research, 1(9), 303-304. https://doi.org/ 10.1177/0972262917733170
Du Plessis, Y., \& Barkhuizen, N. (2012). Psychological capital: A requisite for organizational performance in South Africa. South African Journal of Economics and Management Sciences, 15(1), 16-30. https://doi.org/10.4102/sajems.v15i1.122

Fahmi, I. (2017). Effect of working capital management on profitability of manufacturing companies listed on BEI. E - Journal of Management, 46(3), 387-404.

Fedai, M., \& Kapusuz, A.G.K., (2015). The Relationship Between Job Stress, Burnout, and Clinical Depression. Journal of Affective Disorders, 7(5), 209-221.

Eustace, A., \& Martins, N. (2014). The role of leadership in shaping organisational climate: An example from the FMCG industry. SA Journal of Industrial Psychology/ SA Tydskrifvir Bedryfsielkunde, 4O(1), Art. \#1112, 1-13. https://doi.org/10.4102/ sajip.v40i1.1112

Gu, Z., \& Siu, R.C. (2009). Drivers of job satisfaction as related to work performance in Macao casino hotels an investigation based on employee survey. Internationa Journal of Contemporary Hospitality Management, 21(5), 561-578. https://doi. org/10.1108/09596110910967809

Harter, J. K., Schmidt, F. L. \& Hayes, J.E. (2002). Validation of a performancerelated and actionable management tool: A meta-analysis and utility analysis (Gallup Technical Report). Princeton, NJ: The Gallup Organization.

Heriyati, P., \& Ramadhan, A.S. (2012). The influence of employee satisfaction in supporting employee work performance and retention moderated by the employee engagement factor of an institution (an empirical study of Binus Business School). International Journal of Economics and Management, 6(1), 191-200. https://doi.org/10.14810/ijbbr.2017.6101.1

Herlina, A., \& Mujib, A. (2017). Impact of social support, psychological capital, and workplace spirituality to employee engagement at company. TAZKIYA Journal of Psychology, 22(1), 15-26. https://doi.org/10.15408/tazkiya.v22i1.8151

Hu, L. T, \& Bentler, P. M. (1999). Cutoff Criteria for Fit Indexes in Covariance Structure Analysis: Conventional Criteria versus New Alternatives. Structural Equation Modeling, 6(3), 45-55. http://dx.doi.org/10.1080/10705519909540118

Ibrahim, I.I \& Boerhaneoddin, A. (2010). Is Job Satisfaction Mediating The Relationship Between Compensation Structure And Organisational Commitment? A Study in the Malaysian Power Utility. Journal of Global Business and Economics, Global Research Agency, 1(1), 43-61.

Jung, H., Kang, A., \& Busser, J.A. (2018). Impact of service climate and psychological capital on employee engagement: The role of organizational hierarchy. International Journal of Hospitality Management, 75(2018), 1-9. https://doi.org/ 10.1016/j.ijhm.2018.03.003

Kaplan, M.,\& Mehmet, D. (2013). The relationship between psychological capital and job satisfaction: A study of hotel business in Nevsehir. YÖNETIM VE EKONOMi, 20(2), 233-242. https://doi.org/10.1111/j.1744-6570.2007.00083.x

Kementerian Perindustrian. (2019). Industri keramik pangkas utilisasi hingga $50 \%$. Retrieved from https://www.kemenperin.go.id/artikel/16042/Industri-KeramikPangkas-Utilisasi-Hingga-50.

Kementerian Perindustrian. (n.d.). Kontribusi industri manufaktur Indonesia peringkat keempat dunia. Retrieved from https://www.kemenperin.go.id/artikel/18325/ Kontribusi-Industri-Manufaktur-Indonesia-Peringkat-Keempat-Dunia.

Kurniadewi, E. (2016). Psychological capital dan workplace well-being sebagai Prediktorbagi employee engagament. Jurnal Psikologi Integratif, 4(2), 95-112.

Lockwood, N.R. (2007). Leveraging Employee Engagement for Competitive Advantage: HR`s Strategic Role, Society for Human Resource Management Quarterly, 1(4), 234-562.

Luthans, F., Avolio, B. J., Avey, J. B., \& Norman, S. M. (2007). Positive psychological capital: Measurement and relationship with performance and satisfaction Personnel Psychology, 60, 541-572. https://doi.org/10.5465/ame.2002.6640181

Luthans, F., Norman, S.M., Avolio, B.J., \& Avey, J.B. (2008). The mediating role of psychological capital in the supportive organizational climate - Employee performance relationship. Journal of Organisational Behaviour, 29(2), 219-238. https://doi.org/10.1108/LODJ-01-2015-0005

Macey, W.H, \& Schneider, B. (2015). The meaning of employee engagement. Industrial and Organizational Psychology, 1(1), 3-30.

Mariska, D.D. (2018). Hubungan antara employee engagement dan kepuasan kerja dengan kinerja. Jurnal Insight Fakultas Psikologi Universitas Muhammadiyah Jember, 14(1), 91-98.

Mathis, R.L., \& Jackson, J.H. (2006). Human resource management (Manajemen sumber daya manusia). D. Angelia (Ed.). Jakarta: Salemba Empat.

Mello, J.A., \& Hartford, W. (1962). In support of others: An examination of psychological capital and job satisfaction in academic staff. International Journal Psychological, 12(1), 1-9. https://doi.org/10.1016/j.orgdyn.2015.05.004

Nafei, W. (2015). The effects of psychological capital on employee attitudes and employee performance: A study on teaching hospitals in Egypt. International
Journal of Business and Management, 10(3), 249-270. https://doi.org/10.5539/ Journal of Business
ijbm.v10n3p249

Ncube, F, \& Jerie, S. (2012). Leveraging employee engagement for competitive advantage in the hospitality industry. A comparative study of hotels A and B in
Zimbabwe. Journal of Emerging Trends in Economics and Management Sciences, Zimbabwe. Journal of Emerging Trends in Economics and
3(4), 380-388. https://hdl.handle.net/10520/EJC126570

Nengah, N., Kertiriasih, R., Sujana, I.W., \& Suardika, I.N. (2018). The effect of leadership style to job satisfaction, employee engagement and employee performance (study at PT. Interbat, Bali, Nusra, and Ambon). International Journal of (study at PT. Interbat, Bali, Nusra, and Ambon). International Journal of
Contemporary Research and Review, 9(3), 20592-20600. https://doi.org/10.15520/ Contemporary Research and

Nguwi, M. (2014). Time to rethink employee engagement. Financial Gazette http://all africa. com/stories/201012220113.html Accessed 05 February 2019. https:// www.financialgazette.co.zw/time-to-rethink-employee-engagement/. 
Njoroge S.W., \& Kwasira, J. (2015). Influence of compensation and reward on performance of employees at Nakuru county government. IOSR Journal of Business performance of employees at Nakuru county government. IOSR Journal of Busine
and Management, 17(11), 87-93. https://doi.org/10.9790/487X-171118793

Parthi, K., \& Gupta, R. (2016). A study of psychological capital, job satisfaction and organizational climate in telecom sector: A gender perspective. Diviner, 13(1) 1-6. https://doi.org/ISSN 0973-8320

Platis, C., Reklitis, P., \& Zimeras, S. (2015). Relation between job satisfaction and job performance in healthcare services. Procedia - Social and Behavioral Sciences, 175, 480-487. https://doi.org/10.1016/j.sbspro.2015.01.1226

Pratama, R., \& Aima, M.H. (2018). The effect of compensation and employee engagement on organizational commitments and its implementation toward employee's performance of PT XYZ Jakarta. International Journal of Scientific and Research Publications, 8(12), 360-368. https://doi.org/10.29322/IJSRP.8.12.2018. p8448

Rini, A.S. (2018). Semester $1 / 2018$, impor keramik terus tumbuh. Retrieved from https://ekonomi.bisnis.com/read/20180728/257/821722/semester-i20 18-impor-keramik-terus-tumbuh.

Robbins, P.S. (2006). Perilaku organisasi. B. Molan (Ed.). Sepuluh, Jakarta: Erlangga.

Salam, M.A. (2017). Effects of psychological capital on job satisfaction and turnover intention: Thai higher education perspective. Journal of Asia Pacific Studies, 4(3), 203-218. https://doi.org/10.4314/wsa.v27i3.4986

Schaufeli, W.B., Salanova, M., Bakker, A.B., \& Alez-rom, V.G. (2002). The measurement of engagement and burnout: A two-sample confirmatory factor. Journal of Happiness Studies, 3, 71-92. https://doi.org/10.11560/jahp.25.1_31

Scholar link Research Institute Journals. (2012). Journal of Emerging Trends in Economics and Management Sciences, Human Resource Management Department, Midlands State.
Seligman, M.E.P. (2011). Flourish: A visionary new understanding of happiness and well-being. New York, NY: Free Press.

Sihag, P., \& Sarikwal, L. (2014). Impact of psychological capital on employee engagement: A study of IT professionals in Indian context. Management Studies and Economic Systems, 1(2), 127-139. https://doi.org/10.1371/journal.pone.0067547.22

Suharianto, S., \& Effendy, N. (2015). Pengaruh psychological capital terhadap work engagement Pada dosen di Universitas Katolik Widya Mandala Surabaya. Jurnal Experientia, 3(2), 23-34. https://doi.org/10.14710/jpu.12.2.192-202

Suparyadi, H. (2015). The effect of compensation and work environment on organizationa commitment of employees in bank XXX, Medan. International Journal of Research commitment of employees in
and Review, 7(1), 521-525.

Tepayakul, R., \& Rinthaisong, I. (2018). Job satisfaction and employee engagement among human resources staff of Thai private higher education institutions. The Journal of Behavioral Science, 13(2), 68-81.

Thompson, K.R., Lemmon, G., \& Walter, T.J. (2015). Employee engagement and positive psychological capital. Organizational Dynamics, 44(3), 11. https://doi. org/10.1016/j.orgdyn.2015.05.004

University, Zimbabwe. Department of Geography and Environmental Studies, Midlands State University, Zimbabwe.

Yasmin, P.A. (2018). Keramik RI sulit bersaing lawan produk China, ini penyebabnya Retrieved from https://finance.detik.com/industri/d-4025881/keramik-ri-sulitbersaing-lawan-produk-china-ini-penyebabnya.

Zaman, N., \& Tjahjaningsih, E. (2017). Pengaruh modal psikologidan organizational citizenship behavior terhadap kinerja dimediasi oleh kepuasan kerja. Jurna citizenship behavior terhadap kinerja dimediasi oleh kepuasan kerja. Jurnal
Bisnis Dan Ekonomi, 24(1), 50-61. https://doi.org/10.1037/0021-9010.91.1.193

Zimbabwe National Statistics Agency (ZimStats) (2017). Manufacturing industry survey. Harare: Zimbabwe National Statistics Agency. 